\title{
Erratum to: Development and Implementation of a Health Behavioral Counseling Curriculum for Physician Assistant Cancer Education
}

Robert J. McLaughlin • Carl E. Fasser •

Laurel R. Spence • J. David Holcomb

Published online: 24 August 2010

(C) Springer 2010

Erratum to: J Canc Educ

DOI 10.1007/s13187-010-0038-5

The original publication should have included the following funding information: "Supported in part by National Cancer Institute Grant 1R25CA109743-01A2." The publisher regrets the error.

The online version of the original article can be found at http://dx.doi. org.10.1007/s13187-010-0038-5.

R. J. McLaughlin $(\bowtie) \cdot$ C. E. Fasser $\cdot$ L. R. Spence $\cdot$

J. D. Holcomb

Baylor College of Medicine,

Houston, TX, USA

e-mail: robertm@bcm.edu 